University of Nebraska - Lincoln

DigitalCommons@University of Nebraska - Lincoln

\title{
Linking River Management To Species Conservation Using Dynamic Landscape-Scale Models
}

\author{
M. C. Freeman \\ USGS Patuxent Wildlife Research Center, mcfreeman@usgs.gov \\ G. R. Buell \\ USGS Georgia Water Science Center, grbuell@usgs.gov \\ L. E. Hay \\ USGS, lhay@usgs.gov \\ W. B. Hughes \\ USGS Georgia Water Science Center \\ R. B. Jacobson \\ USGS Columbia Ecological Research Center, rjacobson@usgs.gov \\ See next page for additional authors
}

Follow this and additional works at: https://digitalcommons.unl.edu/usgsstaffpub

Freeman, M. C.; Buell, G. R.; Hay, L. E.; Hughes, W. B.; Jacobson, R. B.; Jones, J. W.; Jones, S. A.; Lafontaine, J. H.; Odom, K. R.; Peterson, J. T.; Riley, J. W.; Schindler, J. S.; Shea, C.; and Weaver, J. D., "Linking River Management To Species Conservation Using Dynamic Landscape-Scale Models" (2012). USGS Staff -- Published Research. 588.

https://digitalcommons.unl.edu/usgsstaffpub/588

This Article is brought to you for free and open access by the US Geological Survey at DigitalCommons@University of Nebraska - Lincoln. It has been accepted for inclusion in USGS Staff -- Published Research by an authorized administrator of DigitalCommons@University of Nebraska - Lincoln. 


\section{Authors}

M. C. Freeman, G. R. Buell, L. E. Hay, W. B. Hughes, R. B. Jacobson, J. W. Jones, S. A. Jones, J. H. Lafontaine, K. R. Odom, J. T. Peterson, J. W. Riley, J. S. Schindler, C. Shea, and J. D. Weaver 


\title{
LINKING RIVER MANAGEMENT TO SPECIES CONSERVATION USING DYNAMIC LANDSCAPE-SCALE MODELS
}

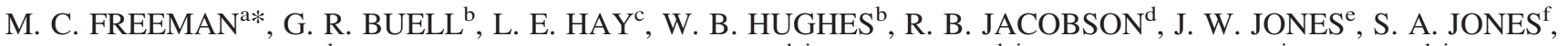 \\ J. H. LAFONTAINE ${ }^{\mathrm{b}}$, K. R. ODOM ${ }^{\mathrm{g}}$, J. T. PETERSON ${ }^{\mathrm{h}, \mathrm{i}}$, J. W. RILEY ${ }^{\mathrm{b}, \mathrm{i}}$, J. S. SCHINDLER ${ }^{\mathrm{j}}$, C. SHEA ${ }^{\mathrm{h}, \mathrm{i}}$ and \\ J. D. WEAVER ${ }^{\mathrm{f}}$ \\ ${ }^{\text {a } U S G S ~ P a t u x e n t ~ W i l d l i f e ~ R e s e a r c h ~ C e n t e r, ~ A t h e n s, ~ G e o r g i a, ~ U S A ~}$ \\ ${ }^{\mathrm{b}}$ USGS Georgia Water Science Center, Atlanta, Georgia, USA \\ ${ }^{c}$ USGS, National Research Program, Lakewood, Colorado, USA \\ ${ }^{\mathrm{d}}$ USGS Columbia Ecological Research Center, Columbia, Missouri, USA \\ ${ }^{\mathrm{e}}$ USGS Eastern Geographic Science Center, Reston, Virginia, USA \\ ${ }^{\mathrm{f}}$ USGS Southeast Area, Norcross, Georgia, USA \\ ${ }^{\mathrm{g}}$ USGS Alabama Water Science Center, Montgomery, Alabama, USA \\ ${ }^{\mathrm{h}}$ USGS GA Cooperative Fish and Wildlife Research Unit, Athens, Georgia, USA \\ ${ }^{\mathrm{i}}$ Warnell School of Forestry and Natural Resources, University of Georgia, Athens, Georgia, USA \\ ${ }^{\mathrm{j}}$ USGS Eastern Region, Reston, Virginia, USA
}

\begin{abstract}
Efforts to conserve stream and river biota could benefit from tools that allow managers to evaluate landscape-scale changes in species distributions in response to water management decisions. We present a framework and methods for integrating hydrology, geographic context and metapopulation processes to simulate effects of changes in streamflow on fish occupancy dynamics across a landscape of interconnected stream segments. We illustrate this approach using a $482 \mathrm{~km}^{2}$ catchment in the southeastern US supporting 50 or more stream fish species. A spatially distributed, deterministic and physically based hydrologic model is used to simulate daily streamflow for sub-basins composing the catchment. We use geographic data to characterize stream segments with respect to channel size, confinement, position and connectedness within the stream network. Simulated streamflow dynamics are then applied to model fish metapopulation dynamics in stream segments, using hypothesized effects of streamflow magnitude and variability on population processes, conditioned by channel characteristics. The resulting time series simulate spatially explicit, annual changes in species occurrences or assemblage metrics (e.g. species richness) across the catchment as outcomes of management scenarios. Sensitivity analyses using alternative, plausible links between streamflow components and metapopulation processes, or allowing for alternative modes of fish dispersal, demonstrate large effects of ecological uncertainty on model outcomes and highlight needed research and monitoring. Nonetheless, with uncertainties explicitly acknowledged, dynamic, landscape-scale simulations may prove useful for quantitatively comparing river management alternatives with respect to species conservation. Published 2012. This article is a U.S. Government work and is in the public domain in the USA.
\end{abstract}

KEY WORDS: aquatic biodiversity; freshwater fishes; hydrologic models; fluvial geomorphology; metapopulation dynamics

Received 9 March 2012; Accepted 23 March 2012

\section{INTRODUCTION}

Globally, ecologists are being asked to forecast ecological outcomes of alternative resource management options, typically in the context of changing climate and land uses (Clark et al., 2001; Araujo and Rahbek, 2006). Management of water availability in streams and rivers provides a prominent example. Population growth and expanding agricultural irrigation are increasing the demands to divert, transfer and store water from stream and river ecosystems (Postel 2000; Postel and Richter 2003; Fitzhugh and Richter

*Correspondence to:M. C. Freeman, USGS Patuxent Wildlife Research Center,110 Riverbend Road, Room 101, Athens, Georgia 30602, USA.

E-mail: mcfreeman@usgs.gov
2004; Sabo et al., 2010). At the same time, the declining capacity of river systems to support native biota, including imperilled species and fisheries, is a primary concern for natural resource managers and conservationists (Pringle et al., 2000, Arthington and Pusey, 2003; Postel and Richter, 2003; Galat et al., 2005; Dudgeon et al., 2006). Both problems - increasing water demands relative to availability and declining viability of aquatic species-will likely be exacerbated by future changes in land use, such as urbanization (Paul and Meyer, 2001; Fitzhugh and Richter, 2004), and climate change (Kundzewicz et al., 2007; Milly et al., 2008; Palmer et al., 2008; Nelson et al., 2009).

This paper illustrates a methodological approach and discusses research challenges for constructing dynamic models that can inform river management in relation to conserving

Published 2012. This article is a U.S. Government work and is in the public domain in the USA. 
aquatic biodiversity across landscapes. We define a landscape in this application as a group of biologically and hydrologically connected streams and their drainage basins. These landscapes will most often be contained within individual basins but could also encompass a group of basins connected by, for example, migratory fauna (e.g. fishes, waterfowl) or human actions (such as interbasin water transfers). Defined in this way, landscapes (covering, e.g. $10^{2}-10^{4} \mathrm{~km}^{2}$ ) often provide the most relevant spatial extent for evaluating management consequences to regional biodiversity or fisheries because local actions such as water diversions can be evaluated in the context of cumulative impacts on ecological condition (Pringle, 2001; Dudgeon et al., 2006).

Tools for predicting outcomes of water management decisions on species conservation within landscapes are not well developed. Site-specific analyses of relations between streamflow and habitat (Bovee et al., 1998) or other resource values (Brizga et al., 2002) are frequently applied to individual streams. However, the large number and potential variety of streams that compose a landscape make it cost-prohibitive to apply these detailed assessments over areas of large extent. At the other end of the spatial scale, generalized relations between hydrologic alteration and ecological responses are being advanced to support regional streamflow policies (Arthington et al., 2006; Poff et al., 2010). Ecologically based, regional policies for limiting changes in streamflow regimes are expected to provide a management starting point for conservation. However, decisions addressing conservation of biota within particular landscapes may ultimately require data and tools that can be tailored to the specific context. That is, resource managers will need answers to questions such as 'Will a particular streamflow policy protects species in this landscape, given concurrent changes in land use or climate patterns?' Such questions fall between those addressed by regional guidelines and site-specific analyses of habitat-flow relations and could be addressed using simulation models that link local (e.g. population persistence) and landscape (e.g. dispersal) processes. In particular, dynamic, spatially explicit models allow scenario analysis for effects of environmental change on species distributions at spatial scales relevant to conservation (Gaff et al., 2000; Akcakaya et al., 2004; Wintle et al., 2005), while identifying research most needed to reduce uncertainty.

Our work focuses on developing dynamic models of stream fish occurrences in a southeastern US river system where management challenges include conserving biodiversity while meeting water-supply demands and accommodating land use changes imposed by a growing human population. As in other regions (Arthington et al., 2006; Dudgeon et al., 2006; Acreman and Ferguson, 2010), natural resource managers and stakeholders in the southeastern
USA are asking what flow levels should be maintained in rivers and streams to protect native biota, how building additional storage reservoirs for water supply could affect imperilled species and, generally, what management strategies might best protect the region's natural heritage over the coming decades. To provide a framework for addressing these questions, we have developed a model that integrates streamflow alteration with fish ecology to predict species viability at a landscape scale.

Our conceptual basis (Figure 1) builds on hypotheses relating broadly defined flow components (large floods, small floods, high-flow pulses, base flows and extreme low flows; King et al., 2003; Postel and Richter, 2003; Richter et al., 2006) to stream fishes by way of population processes (colonization, reproduction and recruitment, and local extinction; Table 1). The influences of landscape context are represented as interactions of local channel condition (shaped by geology, topography, historical land use and flood regime) and water quality parameters (consequences of land use, pollutant loading and natural factors) with streamflow dynamics to influence population persistence (Figure 1). Reach isolation (e.g. by barriers such as stream impoundments) influences population persistence by constraining potential colonization. In this paper, we describe methods for integrating hydrology with metapopulation processes, on the basis of this conceptual model, to simulate effects of changes in streamflow on fish occupancy dynamics. We illustrate a management application of the model by simulating effects of alternative water withdrawal scenarios on species occupancy. We also explore model sensitivity to differing sources of uncertainty and conclude by discussing research directions for improving dynamic landscape-scale model applications to aquatic conservation issues.

\section{METHODS}

\section{Study area}

The upper Flint River system, Georgia, drains approximately $7560 \mathrm{~km}^{2}$ (Figure 2) and provides water for an urbanizing portion of the southeastern US Piedmont. Population growth in the Upper Flint Water Supply Management Area has exceeded $200 \%$ since 1970 (to over 302000 in 2000) and is projected to nearly double again by 2030 (CH2MHill, 2003). Multiple water supply reservoirs, with associated water withdrawals for municipal uses, have been constructed or planned within the upper Flint River system in the past two decades. At the same time, the Flint River is valued for recreational boating and fishing, aesthetic values and for supporting unique biodiversity. The river main stem flows unimpeded by major impoundments for over $350 \mathrm{~km}$ from Piedmont headwaters onto the Southeastern Plains and harbours habitats and biologically diverse 


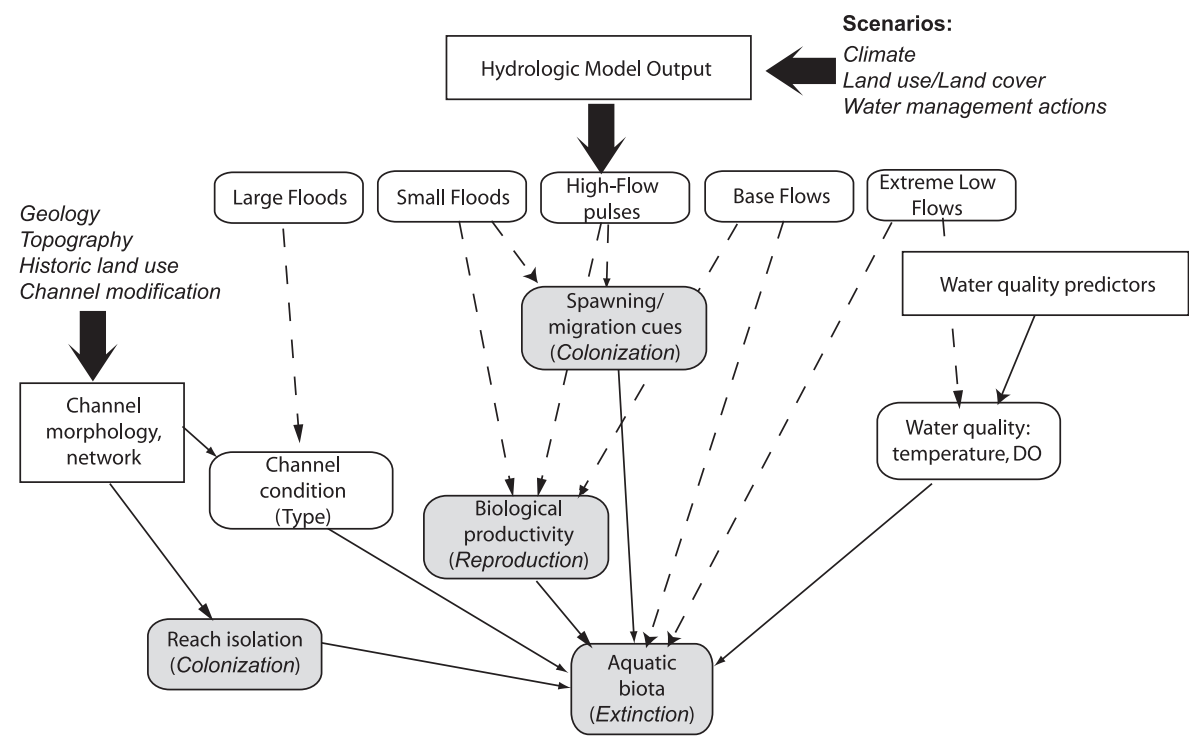

Figure 1. Conceptual basis for the hydrology-metapopulation dynamics model, illustrating streamflow effects (broken arrows) on population processes (shaded boxes). Wide arrows represent multiple connections between model components (e.g. hydrologic model output to individual flow components)

communities of the types eliminated by damming in rivers across the eastern USA (Couch et al., 1996; Pringle et al., 2000). The upper Flint River system supports at least 50 species of native freshwater fishes, including five species endemic to the encompassing Apalachicola Basin, as well as remnant populations of imperilled freshwater mussel species (Brim-Box and Williams, 2000; Williams et al., 2008).

To develop a prototype model, we have focused on metapopulation dynamics of stream fishes in the Potato Creek catchment (Figure 2) within the upper Flint River system. The Potato Creek catchment $\left(482 \mathrm{~km}^{2}\right.$ at USGS gauge 02346500 , the area modelled) contains much of the geographic variation, fish fauna and variety in landscape dynamics present in the upper Flint but with a smaller total number of stream segments. Modelling the Potato Creek catchment has allowed us to evaluate methods for representing spatially explicit geomorphology, streamflow and metapopulation dynamics in a computationally manageable system.

Table I. Streamflow effects on productivity, persistence and movements of temperate stream fishes and represented in the conceptual framework for the hydrology-metapopulation model

\begin{tabular}{lll}
\hline Population process & Streamflow effect & Selected references
\end{tabular}

Biological productivity (recruitment, reproduction and growth)

Persistence (survival)

Movement (migration, dispersal and colonization)
Floods transport sediments and scour substrates, influencing spawning habitat condition.

Floods and high-flow pulses (flow variability) may reduce juvenile fish abundances.

Base flows and high flow pulses influence foodwebs via effects on biotic interactions, periphyton dynamics, organic matter transport and nutrient availability.

Large floods influence channel form, which constrains flow-dependent habitat effects on persistence.

Base flow magnitudes interact with channel form to determine hydraulic habitat availability and potential for biotic interactions.

Extreme low flows limit survival via reduced habitat volume and effects on physiochemical parameters.

High-flow pulses initiate spawning movements by fishes and facilitate migration and dispersal.
Cattaneo et al., 2001

Bain et al., 1988; Freeman et al., 2001; Craven et al., 2010;

Power et al., 1996; Doyle et al., 2005

Rabeni and Jacobson, 1993; Bunn and Arthington, 2002

Peterson et al., 2009; McCargo and Peterson, 2010

Larimore et al., 1959; Bayley and Osborne, 1993; Magoulick and Kobza, 2003

Hall, 1972; Labbe and Fausch, 2000;

Albanese et al., 2004; Franssen et al., 2006

Selected references emphasize studies or reviews most relevant to stream fishes in systems or with traits similar to those in the Potato Creek study system. 


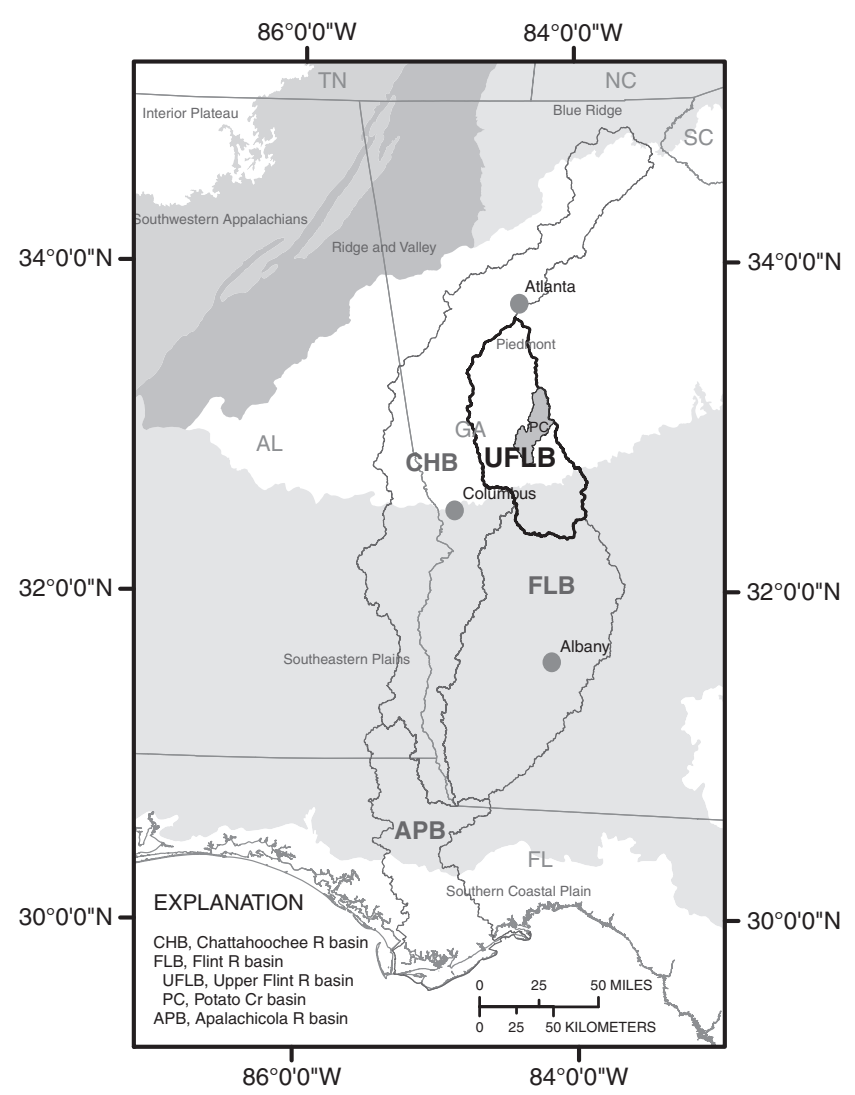

Figure 2. Location of the upper Flint River system (UFLB), Georgia, USA, in the headwaters of the Flint Basin (FLB). The Flint and Chattahoochee (CHB) rivers merge to form the Apalachicola River (APB), which flows to the Gulf of Mexico. The prototype hydrology-metapopulation model was constructed for the Potato

Creek catchment (PC, shaded) contained within the UFLB

\section{Integrated model development}

Overview. Streamflow effects on biota are simulated using modelled hydrologic time series to drive metapopulation state transitions for individual fish species in each stream segment composing a catchment (Figure 3). A stream segment is defined as a reach bounded by tributary junctions, using streams mapped at a 1:24000 resolution. Defined at this relatively fine resolution, we assume that a given fish species is unlikely to be continuously present in all habitable segments, and that frequency of occurrence will increase or decrease as flow conditions either promote or reduce reproduction, survival and dispersal. Geographic layers describing land use, vegetation, topography, parent geology, stream size and slope for the study system are used to predict initial species distributions. We also use geologic and geographic data to parameterize a hydrologic model, which uses daily weather station data (precipitation and temperature) to simulate a corresponding time series of streamflows for catchment sub-basins. Daily streamflows are summarized into seasonal statistics that are used to estimate

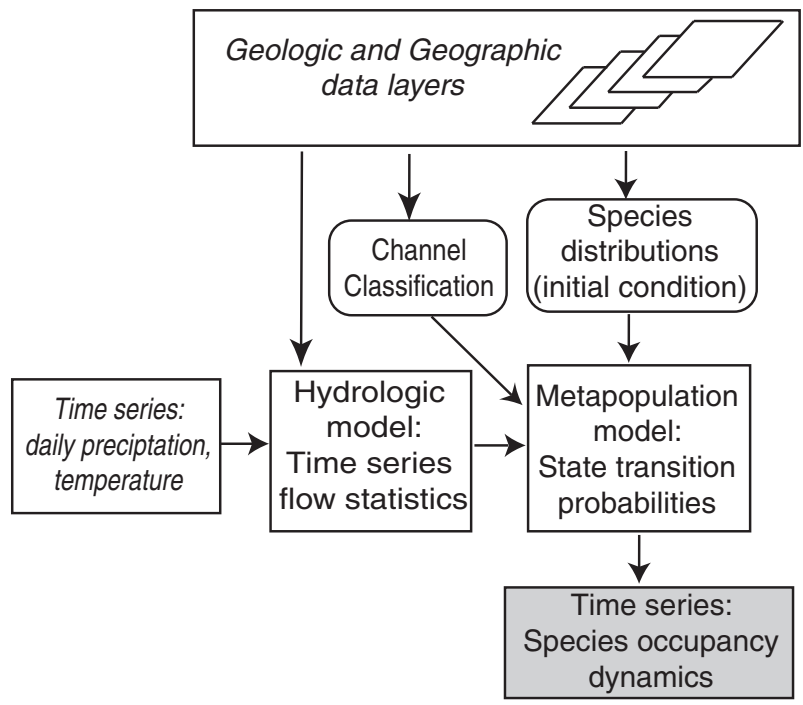

Figure 3. Overview of modelling approach. Geologic and geographic data describing landscape variation are used to parameterize a spatially explicit hydrologic model to classify stream segments according to channel geomorphology, size and network position and to predict species distributions for initial model conditions. By using weather time series as input, the hydrologic model simulates streamflow components, which in turn influence species-specific metapopulation dynamics. Model output (shaded) comprises spatially explicit variation in species occurrences through time

probabilities of metapopulation transitions (i.e. between occupied and unoccupied) in each stream segment, conditional on physical characteristics of each segment and on the identity or characteristics of each species. The outcome is a time series describing spatially explicit, species-specific occupancy dynamics for a given water management, climate and land use scenario. Outcomes can be aggregated, for example, across segments to quantify simulated changes through time in species-specific occurrence frequencies or across species to map temporal changes in community composition. Methods for developing each model component are described in the succeeding text.

Simulating streamflow dynamics. We employ a spatially distributed, deterministic, physically based hydrologic model (USGS Precipitation Runoff Modelling System, PRMS; Leavesley et al., 1983; Leavesley and Stannard, 1995) to simulate spatial and temporal variation in streamflow under current conditions and alternative land use, climate and management scenarios (Viger et al., 2011). PRMS simulates distributed streamflow (a combination of surface, subsurface and groundwater flow) in predefined hydrologic response units (HRUs) composing the catchment. The Potato Creek model uses soil maps (State Soil Geographic database, summarized at a $1-\mathrm{km}$ grid) and the National Land Cover Database (30-m grid resolution) for 2001 to parameterize relative subsurface, land cover and vegetation characteristics 
for each HRU (Viger et al., 2010). The model requires daily inputs of precipitation and maximum and minimum air temperature. These data are derived from the National Weather Service Cooperative Observer Program and distributed to the HRUs by multiple linear regression on the basis of location (latitude and longitude) and altitude (Hay and Clark, 2003; Viger et al., 2010). The Potato Creek model also incorporates effects on streamflow of surface water storage in man-made ponds and depressions scattered across the landscape (Viger et al., 2010).

The hydrologic model is calibrated using a multi-objective, stepwise calibration tool (Hay and Umemoto, 2006; Hay et al., 2006) that adjusts values of selected parameters using the Shuffled Complex Evolution algorithm (Duan et al., 1993) until the difference between simulated and measured streamflow statistics at USGS streamgage locations are minimized. The procedure consists of four calibration steps, addressing (i) mean monthly solar radiation, (ii) mean monthly potential evapotranspiration, (iii) annual and monthly water balance, and (iv) daily streamflow components. The model outlet is at a USGS streamgage on the Potato Creek main stem (station 02346500), from which an 11-year record (1960-1970) of daily streamflows has been used for calibration to best approximate the five seasonal flow statistics included in the fish metapopulation model (described in the succeeding text). Streamflow can be simulated at increasingly finer resolutions by subdividing the model HRUs and calibrating PRMS parameters to provide the best fit of flows summed across sub-basins to measured data, for the flow parameters of greatest interest. To evaluate an effect of hydrologic model resolution on metapopulation simulations, we have partitioned the Potato Creek catchment into HRUs representing two resolutions, 'coarse', in which 20 HRUs average $24.1 \mathrm{~km}^{2}$, and 'fine', in which the coarse units are subdivided into a total of 166 smaller HRUs averaging $2.9 \mathrm{~km}^{2}$.

Representing the geomorphic template. Geomorphic variation among stream segments is expected to mediate ecological responses to changes in flow regime by altering the template of physical habitat and the suite of physical processes operating in a stream segment (Montgomery, 1999; Rabeni and Sowa, 2002; Thorp et al., 2006; Peterson et al., 2009; Poff et al., 2010). Recent research in the Southeastern Plains portion of the Flint River system provides strong support for using channel confinement as a predictor of flow effects on habitat availability (Peterson et al., 2009) and on response of fish species richness and presence to drought flows (McCargo and Peterson, 2010). Additionally, stream size is expected to influence flow dynamics (Thorp et al., 2006) and reach-scale hydraulics (Lamouroux and Cattaneo, 2006), and segment position in the stream network is expected to influence potential for colonization (Osborne and Wiley, 1992; Fagan 2002).
Thus, the physical template for the prototype metapopulation model comprises stream segments (defined in the 1:24000 stream network) categorized by expected channel confinement, stream size and network position relative to larger streams. For the Potato Creek model, we classify segments as 'unconfined' if greater than $10 \%$ of the drainage area polygon assigned to the individual segment has 0 slope, estimated from 30-m resolution digital elevation models. The $10 \%$ threshold is based on exploratory analysis and comparison with classification as 'wetlands' (and thus unconfined) in National Wetland Inventory maps and represents a potential source of channel misclassification. Each segment is additionally attributed by link magnitude (total number of first-order streams in the catchment polygon, a measure of stream size), downstream link (link magnitude of the next downstream reach, a measure of position within the stream network; Osborne and Wiley, 1992) and a binary variable, 'isolated', that is set to 1 if the segment flows directly to an impoundment within a 10-segment buffer. Selection of a 10-segment buffer for defining 'isolation' is an arbitrary choice that compromises between narrow (e.g. direct connection to any other unimpounded segment constitutes 'not isolated') and broad (all segments upstream of any impoundment are 'isolated') definitions and is an additional potential source of misclassification with respect to ecological state.

Simulating biotic response. A multistate metapopulation model (J. T. Peterson, Oregon Cooperative Research Unit, unpublished data) is used to simulate fish species occupancy dynamics across the stream segments composing the Potato Creek catchment. Initial probabilities of occurrence for each of 37 native fish species are estimated for each stream segment, using models relating species occurrence to land use, geology, position in the stream network (downstream link), and reach slope (Ruiz and Peterson, 2007). Changes in species-specific occurrences across the Potato Creek catchment are then simulated by estimating the probabilities of state transitions (local extinction, colonization, reproduction) at each annual time step, as functions of streamflow statistics in the encompassing HRU and segment characteristics. For each stream segment, the initial occupancy status and subsequent state transitions are modelled as draws from a Bernoulli distribution with the corresponding estimated probabilities. For example, if a species is absent from a stream segment in time $t$, presence at time $t+1$ is simulated using a Bernoulli distribution with a probability of success equal to the estimated colonization probability.

Streamflow effects on metapopulation state-transition probabilities could be derived from a variety of sources, including empirical data or expert opinion. For the Potato 
Creek model, streamflow effects on transition probabilities were estimated from an empirical dataset comprising fish species and life stage occurrences observed seasonally over 4 years in 23 stream reaches located in the lower Flint River basin (McCargo and Peterson, 2010; J. T. Peterson, unpublished data). The lower Flint study included observations across severe drought, normal and wet conditions, for adults and juveniles of 42 fish species, 41 of which were present in both the upper and lower portions of the Flint River basin. State-transition probabilities were estimated using hierarchical multiple regression of response variables (observed changes in state in each seasonal time step) as functions of independent variables (streamflow during the time step, channel characteristics, species traits) and taxa-specific detection probabilities. Streamflow ('flow') during each time step was quantified using variables selected to represent five general flow components included in our conceptual model (Figure 1): median daily flow (representing base flow), standard deviation of daily flows (flow pulses), maximum 10-day moving average of daily flow (high flows), minimum 10-day moving average of daily flow (low flows) and the minimum 10-day standard deviation of daily flow (flow stability). Flow values were estimated separately for spring (March-June) and summer (July-September) seasons and normalized to the corresponding long-term, site-specific average for use as predictors of state transitions at each site in the dataset. State-transition probabilities were additionally modelled as functions of stream size (link magnitude), channel type, reach location (dlink magnitude) and species traits (including maximum size, habitat preferences, reproductive timing and duration; Craven et al., 2010). Relative support for alternative models relating probabilities of colonization, reproduction and extinction to these predictor variables was evaluated using an information theoretic approach (J. T. Peterson, unpublished data).

Parameter values from best-supported models using the lower Flint River dataset are used to simulate metapopulation dynamics for the Potato Creek model. In all model runs, streamflow is simulated on a daily time step and aggregated to the five seasonal statistics described earlier, normalized to the HRU-specific seasonal averages for the simulation period (1952-2006). Normalized spring and summer flow statistics are used as predictors of seasonal state transitions, which are summarized as year-to-year changes in occupancy. Failure of a species to recruit young-of-year within timeframes scaled to species-specific generation times results in local extinction.

Evaluating model sensitivity. We simulated species-specific occupancy dynamics under two scenarios. The first scenario represented historic flow conditions, simulated for 19522006 and was used to analyse model sensitivity to error and underlying assumptions. We estimated effects of hydrologic model error and choice of HRU resolution, channel misclassification and uncertainty in hydrologymetapopulation linkages on simulated species richness, a widely used measure of ecological communities and biodiversity, averaged across all segments. We then compared variation in simulated species richness resulting from model uncertainty with changes in average species richness simulated during a severe drought (2000-2001) using the best-supported model from the lower Flint dataset. This comparison provided a measure of the extent to which model uncertainty could overwhelm projected effects of extreme events on biological condition. We also examined effects of assumptions about fish dispersal on simulation outcomes using two alternative dispersal models. The first dispersal model ('mainland-island dispersal'; Hanski and Gilpin, 1991) allowed fish to colonize tributary segments, provided the species was present in the mainstream of Potato Creek, and the segment was not isolated by an impoundment. The second dispersal model ('classic metapopulation dispersal'; Levins, 1969) allowed colonization only from adjacent occupied segments that were within a distance of $7 \mathrm{~km}$.

The second scenario illustrated model application to management questions by simulating effects of four levels of water withdrawal from the main stem of Potato Creek on downstream fish species occurrence. A monthly average withdrawal of $1.9,3.8,7.6$ or 15 million litres per day $(0.5$, 1,2 , or $4 \mathrm{MGD}$ ) was simulated at a point approximately midway along the length of Potato Creek, where transit time to the downstream terminus of the modelled system (at USGS gauge 02346500 in Thomaston GA) was $<24 \mathrm{~h}$. Water withdrawals were simulated as modifications to the historical flow conditions (1952-2006). Empirical relations between actual water use at Thomaston (1980-2000), time of year (month) and monthly precipitation were used to adjust the simulated withdrawal to mimic realistic seasonal patterns in demand and withdrawal rates. Additionally, withdrawals were reduced in the simulations as necessary to maintain streamflow at or above the 7Q10 flow (i.e. 7-day, 1-in-10 year low flow, a statistic used by the State of Georgia to regulate withdrawals) and were halted if flow fell below the 7Q10 statistic to mimic regulatory requirements. Occupancy dynamics for the study system downstream from the withdrawal were simulated using four alternative but plausible models on the basis of the lower Flint River dataset (J. T. Peterson, unpublished data) for effects of flow on reproduction and local extinction and assuming mainland-island colonization dynamics. For all four models, colonization was simulated as a function of maximum 10-day flow, and flow was modelled at the coarse HRU resolution. Our purpose was to examine effects of alternative assumptions regarding hydrology-metapopulation linkages on simulated, management-relevant outcomes (i.e. effects of water withdrawal on stream fishes). 
All scenario and model combinations were simulated for 500 model runs. Each model run resulted in a time series of metapopulation transitions, driven in part by the scenariospecific simulation of daily streamflows, from which annual fish species presence and species richness were simulated. Species richness was calculated as the number of species present for each year and stream segment combination. Mean species richness and occupancy rate (i.e. proportion of simulations in which a segment was occupied) were calculated for each stream segment and year combination by averaging values across the 500 model runs. The sensitivity of estimated species richness to model assumptions and error was evaluated using a one-way value sensitivity analysis (Clemen, 1996). The effect of water use on fishes was examined by calculating the change in estimated species richness and fish occupancy rate compared with the no water-use scenario for the segments containing, and downstream of, the simulated withdrawal point.

\section{RESULTS}

\section{Model simulation results-hydrology and geomorphic template}

Metrics representing the major flow components identified as drivers in the conceptual framework were calculated from daily flow simulations using PRMS for the Potato Creek catchment. Simulated streamflows matched the measured data fairly well on an annual and monthly basis. An analysis of daily streamflow using the Nash-Sutcliffe test statistic (Nash and Sutcliffe, 1970) resulted in annual values ranging from 0.2 to 0.9 , with the median value for the calibration period being 0.8. A Nash-Sutcliffe value of 1.0 would indicate a perfect match with the measured data, and a negative value would indicate that the annual mean simulated the daily streamflow as well as the model. Comparison of simulated and measured seasonal flow statistics (Figure 4) for the calibration period showed generally good matches for median and maximum flows and for flow stability (10-d standard deviation in flow). The model tended to overestimate springtime minimum flows and to underestimate flow variation in the spring and also underestimated flow stability (i.e. overestimated minimum 10-d standard deviation of flow) in two of 11 summers (Figure 4).

The stream network defined for the Potato Creek study area comprised 1391 stream segments, ranging in link magnitude from 1 (headwater streams, approximately half of the segments) to 699 (the downstream most segment of the Potato Creek main stem). Most segments represented in the model were classified as 'confined' (76\%) and 'not isolated' (94\%). Approximately, half of the segments had a downstream link of seven or less, and thus were connected to relatively small streams.
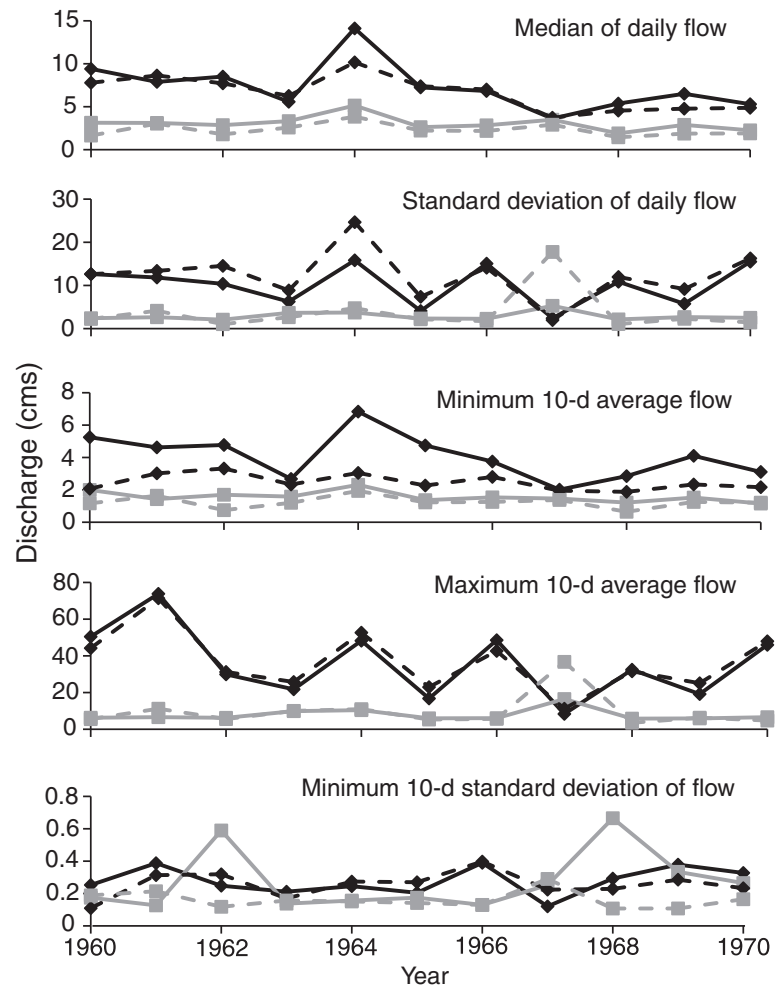

Figure 4. Measured (broken lines) and simulated (solid lines) streamflow statistics for an 11-year calibration period for the Potato Creek catchment precipitation-runoff model. Median and standard deviation of daily flow, minimum and maximum 10-d average flow and minimum 10-d standard deviation of flow are plotted annually for spring (black lines) and summer (grey lines) seasons

\section{Model simulation results-metapopulation dynamics and response sensitivity}

Species occupancy dynamics for stream fishes were responsive to year-to-year variation in streamflow. For example, simulations across the drought of 2000-2001 showed lowered species richness particularly in headwaters more distant from the main stem, with richness recovering in years following the drought (Figure 5). Averaged over all segments, simulated species richness declined from 22 to 17 during the drought. In these simulations, using the best-supported hierarchical regression models on the basis of the lower Flint River dataset, local extinction was modelled as a function of seasonal 10-day minimum flow, and colonization and reproduction were functions of seasonal 10-day maximum flow. Dispersal was allowed to occur from the main stem to connected tributaries. However, analysis of the lower Flint dataset also provided support for modelling extinction and colonization as functions of seasonal median flows and reproduction as a function of the standard deviation of summer flows (J. T. Peterson, unpublished data). Using these alternative models (particularly for 


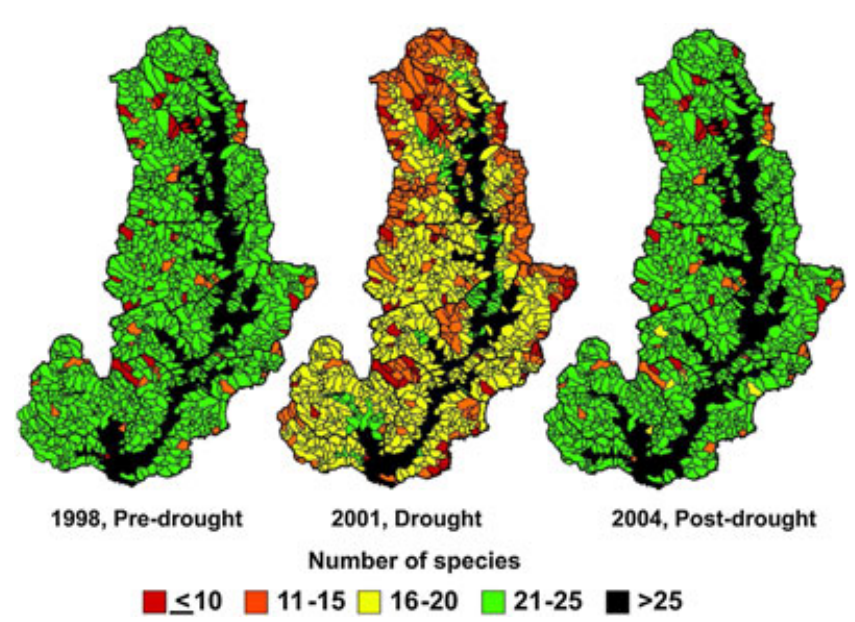

Figure 5. Changes in fish species richness as simulated across a period of severe drought in the Potato Creek catchment, using best-supported models of metapopulation dynamics in relation to streamflow parameters and allowing colonization from the main stem to tributaries. The sequence illustrates species loss in individual stream segments during the peak of the drought (2001), especially from headwaters most distant from the Potato Creek main stem (darkest HRUs in the centre of each diagram) and recovery following the drought

extinction probability) or specifying an alternate model for dispersal (i.e. from nearby occupied reaches) resulted in almost as much difference in estimated average species richness across the full simulation period (1952-2006) as was simulated to occur across an extreme drought (Figure 6).

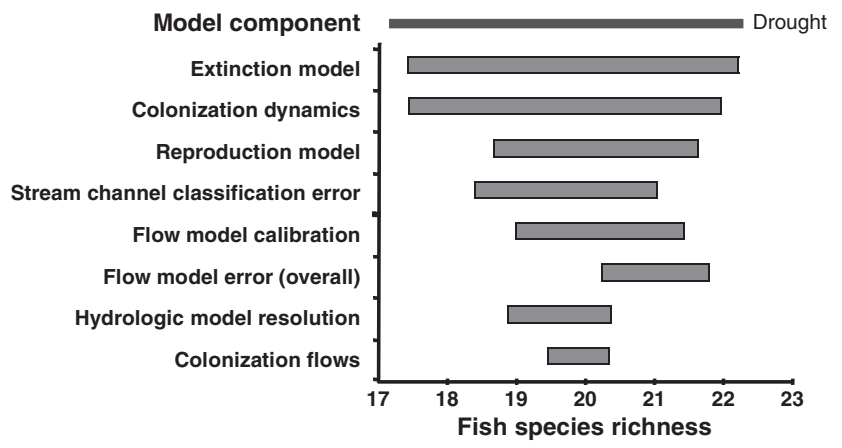

Figure 6. Sensitivity of simulated species richness in the Potato Creek basin to uncertainty in model components, listed from greatest (top) to least influential. Bar lengths represent the range of estimated species richness in an average stream segment obtained by varying the flow component driving extinction, reproduction and colonization, allowing colonizers to originate either in adjacent occupied reaches or occupied main stem reaches ('colonization dynamics'), applying error in geomorphic classification and hydrologic simulations, calibrating hydrologic models to differing flow values and modelling hydrology at coarse versus fine resolution. For comparison, the uppermost bar represents the simulated effect of drought on average species richness, using the bestsupported models for metapopulation dynamics and allowing colonization from main stem to tributaries
Model outcomes were less sensitive to channel misclassification (set at 33\%), choice of flow parameter as priority for PRMS calibration, flow model error (set at $\pm 3.2 \%$ in spring months and $\pm 10 \%$ in summer months) and HRU resolution (coarse versus fine; Figure 6).

Simulated response of fishes to water extraction from Potato Creek for the 54-year period illustrated species differences in responses and, again, model sensitivity to assumed mechanisms. For example, habitat-generalist species such as mosquito fish (Gambusia spp.) showed almost no change in occupancy rate with increasing water extraction, whereas occupancy rates of flow-dependent species (e.g. Apalachicola redhorse, Moxostoma sp. cf. $M$. poecilurum and blackbanded darter, Percina nigrofasciata) declined by as much as 19\% (Figure 7). Total species richness declined with increasing water use, but the severity of decline depended on choice of metapopulation models (Figure 7). Specifically, simulated reductions in species richness were more severe if extinction probabilities were modelled as a function of minimum flow events rather than median flow levels (Figure 7). In contrast, the extraction
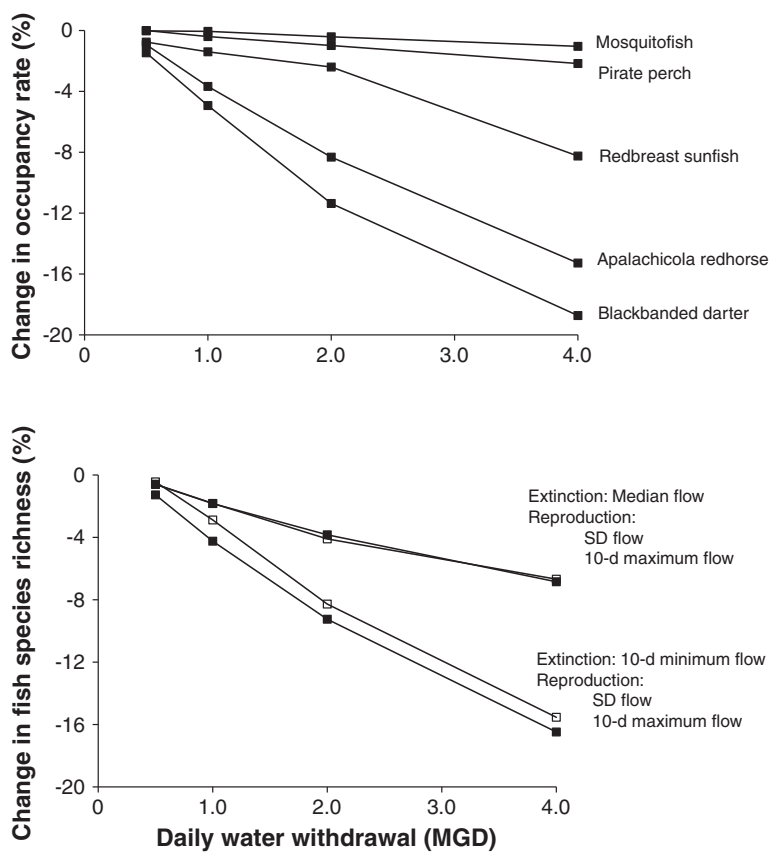

Figure 7. Simulated outcomes of increasing levels of water withdrawal from Potato Creek on downstream fish occupancy, averaged across segments, for a 54-year simulation. Top: Examples of species-specific responses to increasing withdrawal (illustrated for mosquitofish Gambusia spp., pirate perch Aphredoderus sayanus, redbreast sunfish Lepomis auritus, Apalachicola redhorse, Moxostoma sp. cf. M. poecilurum, blackbanded darter, Percina nigrofasciata). Bottom: Effects of alternate choices of flow components as drivers of extinction and reproduction probabilities on species richness response to increasing withdrawal. Withdrawal level is expressed as million gallons per day (MGD); $1 \mathrm{MGD}=3785 \mathrm{~m}^{3}$ day $^{-1}$ 
scenarios had minor effects on high flows and flow variability, so choice of models for reproduction did not strongly affect outcomes (Figure 7).

\section{DISCUSSION}

The coupled hydrology-metapopulation modelling approach developed in this work is intended to provide natural resource stakeholders a tool for exploring effects of water management scenarios on stream biota in the context of specific landscapes. The approach addresses a recognized need for river management tools that integrate physical and biological processes (Anderson et al., 2006; Tetzlaff et al., 2007; Petts, 2009; Vaughan et al., 2009), in part, to allow predictions of outcomes for novel combinations of future land use, water use and climate. Our analysis illustrates the feasibility of simulating streamflow and metapopulation dynamics in a spatially explicit framework that can account for multiple linkages between streamflow and population processes. Dynamic, age-structured (Peterson and Kwak, 1999) and individual-based (Van Winkle et al., 1998; Morales et al., 2006; Railsback et al., 2009) models have been used to simulate mussel and fish population responses to flow variability within individual stream reaches. Simulating metapopulation dynamics provides an approach for scaling-up to predict species persistence across a network of geomorphically variable stream reaches or habitat patches (Stelter et al., 1997) in response to future scenarios of streamflow. Our analysis also illustrates the large effects of model uncertainty on projected outcomes, highlighting areas where research and monitoring could substantially increase understanding and improve model usefulness for management.

Uncertainty regarding biological dynamics stems from incomplete understanding of the complex interplay of streamflow dynamics and ecological processes (Doyle et al., 2005; Anderson et al., 2006; Naiman et al., 2008). Even the simple conceptual framework used here specifies possible influences of multiple flow components on alternative biological processes (migration, productivity and survival), and this accords with general ecological understanding (Bunn and Arthington, 2002). Quantitatively separating these effects using observation data is likely to be difficult. Explorations of biotic conditions across gradients of flow variables commonly show support for multiple flowecology relations (Roy et al., 2005; Knight et al., 2008; Konrad et al., 2008; Kennen et al., 2010). Correlation among values for streamflow components even within a particular season can also result in empirical support for differing hypotheses of how flows affect population processes (Craven et al., 2010; Peterson et al., 2011). For example, fish survival during dry summers may be empirically related to reductions in median flows (and potentially in habitat, food availability, refugia from predators) or to lowered minimum flows (with potentially acute stress from exposure, extreme temperatures or depressed dissolved oxygen). As illustrated here, the choice between modelling local species extinction as a function of median flow levels versus minimum flows can result in substantial differences among population projections for water management or climate scenarios. Assumptions regarding the relative importance of the catchment main stem as a source of colonists for fishes following extreme events (Labbe and Fausch, 2000; Albanese et al., 2009) also substantially influence projected metapopulation dynamics. Better understanding of fish dispersal dynamics will be important for forecasting effects of flow diversions or stream impoundments that isolate headwaters from downstream parts of a stream network.

Monitoring data can reduce uncertainties about ecological mechanisms, particularly if data can be compared with measurable projections derived using alternative hypotheses (Williams et al., 2007). In addition to hypotheses regarding mechanisms of flow effects on biota, noted previously, the landscape-scale approach presented here also entails testable, hypothesized effects of channel geomorphology and segment location within the stream network on ecological dynamics. Dynamic simulation models offer a particular benefit for testing projected outcomes with monitoring data because both time and space can be explicitly specified. For example, a coupled hydrology-metapopulation model can provide expected changes in species occurrences given particular flow events, such as a series of especially wet or dry years, in specific classes of streams or parts of the landscape. Testing projections of ecological dynamics should help narrow the considerable uncertainty in general relations describing ecological response to flow alteration (Poff and Zimmerman, 2010) and would be an integral part of applying a dynamic modelling approach to management and conservation.

Increasing availability of remote sensing data can reduce the inherent uncertainty in the physical components of dynamic landscape models. For example, calibration of the hydrologic model for Potato Creek has already been substantially improved by incorporating depression-storage effects of thousands of uncatalogued ponds, detected using Landsat 7 Enhanced Thematic Mapper (USGS, Sioux Falls, South Dakota, USA) images taken during wet conditions (Viger et al., 2010). Remote sensing data can also be used to quantify seasonal and multiyear fluctuations in vegetation dynamics driven by climate and management, which in turn influence stream hydrology via effects on evapotranspiration rates (Jones and Desmond, 1998; Jones, 2002). Future hydrologic models may accommodate shorter timeframe variations in vegetation condition, either captured through remote sensing or modelled separately, to improve the accuracy of streamflow projections. 
Characterizing ecologically relevant geomorphic variability across a stream system entails challenges in mapping and potentially in projecting channel dynamics. Bedrock geology can be useful in inferring channel form and process because bedrock below or adjacent to a stream channel exerts a direct control on channel morphology largely independent of flow regime (Schumm, 2005). Unfortunately, geologic maps in many landscapes have been compiled at scales that are too coarse to apply at the stream segment scale, and geologic mapping units often are not defined in ways that relate to erodibility. Using digital elevation model-derived slopes to predict channel confinement provides a starting point for characterizing geomorphic context; however, errors in channel classification demonstrably affect model outcomes. Increased availability of high-resolution light detection and ranging-derived elevation datasets is expected to improve maps of spatial variability in channel characteristics across stream networks.

Projecting future stream channel condition poses a different challenge. Legacy sediment (Trimble, 1974; Jackson et al., 2005; Walter and Merritts, 2008) and modern land-use practices interact with watershed topography and geology to result in ongoing dynamic changes to the physical habitat template (Jacobson and Coleman, 1986). For example, studies of Georgia Piedmont streams have identified complex, ongoing adjustments characterized by channel incision in urban areas and variable channel responses in rural areas (Riley, 2009; Riley and Jacobson, 2009), although historical data are not sufficient to predict rates and locations of channel adjustment. Nevertheless, the fact that dynamic adjustments are occurring is important to acknowledge for long-term water resources and conservation planning. Of particular interest is the probability that a reach will undergo transition from one class to another, for example, from an unconfined (wide, shallow) to confined (narrow, deep) alluvial channel, as a result of channel incision in urbanizing watersheds.

Improving representation of water quality effects on metapopulation dynamics often will require new data. For example, water-quality data currently available in the Flint River basin are mostly limited to intermittent samples and short periods of continuous water-quality parameters collected by the USGS, a situation typical of many areas of the southeastern USA and elsewhere. Additionally, given the broad array of water quality parameters that potentially influence biota, it may be reasonable to use observed correlations among land use, water quality and biotic composition (Meador and Goldstein, 2003; Gregory and Calhoun, 2007; Calhoun et al., 2008) to infer indirect predictors of water quality effects on species occurrence. Thus, in the Potato Creek model, we use previously estimated effects of urban and row crop-agriculture land use on speciesspecific occurrence probabilities for fishes in the Flint River basin (Ruiz and Peterson, 2007) to initialize model conditions. A next step in model refinement would be to monitor species occupancy, streamflow and water quality dynamics in streams receiving runoff from varying land uses and use those data to parameterize direct water quality effects on metapopulation transition probabilities.

\section{Model application}

Issues of model evaluation and complexity could impede broad application of the approach presented here to actual management situations. Model evaluation requires measured data that can be compared with predicted values. Although this is feasible for models predicting hydrology and geomorphic form, the scarcity of replicated, long-term data for occurrences of stream biota means that evaluation of the metapopulation dynamics model will require new monitoring data. This limitation also applies to development of generalized flow-ecology relations; in both cases, an adaptive management implementation is seen as essential for evaluating and improving the theoretical models used to inform management (Poff et al., 2010 and discussed previously).

The complexity issue is double-edged. The approach developed here is both a greatly simplified representation of flow-ecology dynamics, and yet may be perceived as too data-intensive for general use. Hydrologic models, however, are now commonly used in resource management (Poff et al., 2010), as are geographic information systems. Whereas data scarcity may limit biological validation, metapopulation models may be developed using relatively short (e.g. three to four generation time spans) time series of species occupancy observations. We suggest this is a valid and feasible approach if the intent is to apply models in an adaptive management framework. In addition, the capacity to generate measurable predicted biological outcomes in a spatially explicit context may justify the cost of model development when management decisions involve highly valued resources.

Integrated hydrology-metapopulation models could also be useful for generating predicted flow-ecology relations in support of regional flow policy development (Arthington et al., 2006; Poff et al., 2010). Specifically, stakeholders could use these models to compare biological outcomes under alternative management scenarios and, importantly, for alternative hypothesized linkages between flow alteration and biological processes. Identifying ecological uncertainties that most strongly influence projected outcomes can guide investments in future research and monitoring.

\section{CONCLUSIONS}

Models that couple hydrology and metapopulation dynamics in a landscape context offer a novel approach for 
quantitatively comparing effects of alternative management actions on stream biodiversity. There is much potential for expanding the modelled interactions, depending on management targets and data availability. For example, interactions with host fishes could be critical to include in models for freshwater mussel species; these and other interactions (e.g. between nest-associating fishes or predators and prey) could be incorporated as conditions on metapopulation state transitions. Research will be needed to narrow uncertainty in model structure (what flow components drive ecological processes, how flow-ecology relations are modified by variation in water quality and stream geomorphology) and to improve characterization of landscape and hydrologic dynamics. However, as illustrated here, the tools are presently available to begin applying plausible hypotheses of flow effects on metapopulation processes to evaluate cumulative, landscape-scale effects of water management, land use and climate change on aquatic species distributions and persistence.

\section{ACKNOWLEDGEMENTS}

We are grateful to the following colleagues who have contributed their ideas to this effort at varying stages of its development. Tom Annear, Steve Earsom, Pierre Glynn, Jonathan Kennen, Gary Krizanich, Helaine Markewich and Brian Richter participated in problem scoping and model conceptualization; Tom Annear, Ken Bovee, Jonathan Kennen, George Leavesley, Jonathan Nelson, LeRoy Poff, Michael Runge and Terry Waddell have provided review comments on project science. Suggestions by Ken Bovee and Catherine Pringle and several anonymous referees substantially improved earlier drafts of this manuscript. We also appreciate constructive input from numerous colleagues in resource management agencies including the US Fish and Wildlife Service and the Georgia Department of Natural Resources. The Georgia Cooperative Fish and Wildlife Research Unit is sponsored by the US Geological Survey, the US Fish and Wildlife Service, the Georgia Department of Natural Resources, the University of Georgia and the Wildlife Management Institute.

\section{REFERENCES}

Acreman MC, Ferguson AJD. 2010. Environmental flows and the European Water Framework Directive. Freshwater Biology 55: 32-48.

Akcakaya HR, Radeloff VC, Mladenoff DJ, He HS. 2004. Integrating landscape and metapopulation modeling approaches: viability of the sharptailed grouse in a dynamic landscape. Conservation Biology 18: 526-537.

Albanese B, Angermeier PL, Dorai-Raj S. 2004. Ecological correlates of fish movement in a network of Virginia streams. Canadian Journal of Fisheries and Aquatic Sciences 61: 857-869.

Albanese B, Angermeier PL, Peterson JT. 2009. Does mobility explain variation in colonization and population recovery among stream fishes? Freshwater Biology 54: 1444-1460.
Anderson KE, Paul AJ, McCauley E, Jackson LJ, Post JR, Nisbet RM. 2006. Instream flow needs in streams and rivers: the importance of understanding ecological dynamics. Frontiers in Ecology and the Environment 4: 309-318.

Arthington AH, Pusey BJ. 2003. Flow restoration and protection in Australian rivers. River Research and Applications 19: 377-395.

Arthington AH, Bunn SE, Poff NL, Naiman RJ. 2006. The challenge of providing environmental flow rules to sustain river ecosystems. Ecological Applications 16: 1311-1318.

Araujo MB, Rahbek C. 2006. How does climate change affect biodiversity? Science 313: 1396-1397.

Bain MB, Finn JT, Booke HE. 1988. Streamflow regulation and fish community structure. Ecology 69: 382-392.

Bayley PB, Osborne LL. 1993. Natural rehabilitation of stream fish populations in an Illinois catchment. Freshwater Biology 29: 295-300.

Bovee KD, Lamb BL, Bartholow JM, Stalnaker CB, Taylor J, Henriksen J. 1998. Stream habitat analysis using the instream flow incremental methodology. USGS/BRD-1998-0004, U.S. Geological Survey, Reston, VA.

Brim-Box J, Williams JD. 2000. Unionid mollusks of the Apalachicola Basin in Alabama, Florida, and Georgia. Bulletin of the Alabama Museum of Natural History 21: 1-143.

Brizga SO, Arthington AH, Choy SJ, Kennard MJ, Mackay SJ, Pusey BJ, Werren GL. 2002. Benchmarking, a 'top-down' methodology for assessing environmental flows in Australian rivers. In Environmental Flows for River Systems Working Conference and Fourth International Ecohydraulics Symposium. 3-8 March 2002, Cape Town: South Africa; 33.

Bunn SE, Arthington AH. 2002. Basic principles and ecological consequences of altered flow regimes for aquatic biodiversity. Environmental Management 30: 492-507.

Calhoun DL, Gregory MB, Weyers HS. 2008. Algal and invertebrate community composition along agricultural gradients: a comparative study from two regions of the eastern United States. U.S. Geological Survey Scientific Investigations Report 2008-5046, 33.

Cattaneo F, Carrel G, Lamouroux N, Breil P. 2001. Relationship between hydrology and cyrpinid reproductive success in the lower Rhone at Montelimar, France. Archiv für Hydrobiologie 151: 427-450.

CH2MHill. 2003. North Georgia regional water supply needs assessment, prepared for Georgia Department of Natural Resources: Atlanta, GA.; 221.

Clark JS, Carpenter SR, Barber M, Collins S, Dobson A, Foley JA, Lodge DM, Pascual M, Pielke R Jr, Pizer W, Pringle C, Reid WV, Rose KA, Sala O, Schlesinger WH, Wall DA, Wear D. 2001. Ecological forecasts: an emerging imperative. Science 293: 657-660.

Clemen RT. 1996. Making Hard Decisions, 2nd edn. Duxbury: Belmont, California.

Couch CA, Hopkins EH, Hardy PS. 1996. Influences of environmental settings on aquatic ecosystems in the Apalachicola-Chattahoochee-Flint River Basin. U.S. Geological Survey Water-Resources Investigations Report 95-4278; 58.

Craven SW, Peterson JT, Freeman MC, Kwak TJ, Irwin E. 2010. Modeling the relations between flow regime components, species traits, and spawning success of fishes in warmwater streams. Environmental Management 46: 181-194.

Doyle MW, Stanley EH, Strayer DL, Jacobson RB, Schmidt JC. 2005. Effective discharge analysis of ecological processes in streams. Water Resources Research 41: W11411. DOI: 10.1029/2005WR004222.

Duan Q, Gupta VK, Sorooshian S. 1993. A shuffled complex evolution approach for effective and efficient global minimization. Journal of Optimization Theory and Its Applications 76: 501-521.

Dudgeon D, Arthington AH, Gessner MO, Kawabata Z-I, Knowler DJ, Leveque C, Naiman RJ, Prieur-Richard A-H, Soto D, Stiassny MLJ, Sullivan CA. 2006. Freshwater biodiversity: importance, threats, status and conservation challenges. Biological Review 81: 163-182. 
Fagan WF. 2002. Connectivity, fragmentation, and extinction risk in dendritic populations. Ecology 83: 3243-3249.

Fitzhugh TW, Richter BD. 2004. Quenching urban thirst: growing cities and their impacts on freshwater ecosystems. BioScience 54: 741-754.

Franssen NR, Gido KB, Guy CS, Tripe JA, Shrank SJ, Strakosh TR, Bertrand KN, Franssen CM, Pitts KL, Paukert CP. 2006. Effects of floods on fish assemblages in an intermittent prairie stream. Freshwater Biology 51: 2072-2086.

Freeman MC, Bowen ZH, Bovee KD, Irwin ER. 2001. Flow and habitat effects on juvenile fish abundance in natural and altered flow regimes. Ecological Applications 11: 179-190.

Gaff H, DeAngelis DL, Gross LJ, Salinas R, Shorrosh M. 2000. A dynamic landscape model for fish in the Everglades and its application to restoration. Ecological Modelling 127: 33-52.

Galat DL, Berry CR, Gardner WM, Hendrickson JC, Mestl GE, Power GJ, Stone C, Winston MR. 2005. Spatiotemporal patterns and changes in Missouri River fishes. In Historical Changes in Large River Fish Assemblages of the Americas, Rinne JN, Hughes RM, Calamusso R (eds). American Fisheries Society Symposium 45: Bethesda, Maryland; 249-291.

Gregory MB, Calhoun DL. 2007. Physical, chemical, and biological responses of streams to increasing watershed urbanization in the Piedmont Ecoregion of Georgia and Alabama. In Effects of urbanization on stream ecosystems in six metropolitan areas of the United States, U. S. Geological Survey Scientific Investigations Report 2006-5101B, 104.

Hall CAS. 1972. Migration and metabolism in a temperate stream ecosystem. Ecology 53: 585-604.

Hanski I, Gilpin M. 1991. Metapopulation dynamics: brief history and conceptual domain. Biological Journal of the Linnean Society 42: 3-16.

Hay LE, Clark MP. 2003. Use of statistically and dynamically downscaled atmospheric model output for hydrologic simulations in three mountainous basins in the western United States. Journal of Hydrology 282: 56-75.

Hay LE, Umemoto M. 2006. Multiple-objective stepwise calibration using Luca. U.S. Geological Survey Open-File Report 2006-1323. 25.

Hay LE, Leavesley GH, Clark MP, Markstrom SL, Viger RJ, Umemoto M. 2006. Step wise multiple objective calibration of a hydrologic model for a snowmelt dominated basin. Journal of the American Water Resources Association 42: 877-890.

Jackson CR, Martin JK, Leigh DS, West LT. 2005. A southeastern piedmont watershed sediment budget: Evidence for a multi-millennial agricultural legacy. Journal of Soil and Water Conservation 60: 298-310.

Jacobson RB, Coleman DJ. 1986. Stratigraphy and recent evolution of Maryland Piedmont flood plains. American Journal of Science 286: 617-637.

Jones JW. 2002. The importance of vegetation fluctuations for macroscale watershed streamflow. Doctoral Dissertation. University of Maryland Department of Geography. 194.

Jones JW, Desmond GB. 1998. Land characterization for hydrologic modeling in the Everglades. In Applications of Remote Sensing in Hydrology_Proceedings of the Fourth International Workshop on Remote Sensing in Hydrology. Santa Fe, NM, U.S.A. Saskatoon: NHRI; 123-133

Kennen JG, Riva-Murray K, Beaulieu KM. 2010. Determining hydrologic factors that influence stream macroinvertebrate assemblages in the northeastern U.S. Ecohydrology 3: 88-106.

King J, Brown C, Sabet H. 2003. A scenario-based holistic approach to environmental flow assessments for rivers. River Research and Applications 19: 619-639.

Knight RR, Gregory MB, Wales AK. 2008. Relating streamflow characteristics to specialized insectivores in the Tennessee River Valley: a regional approach. Ecohydrology 1: 394-407.

Konrad CP, Brasher AMD, May JT. 2008. Assessing streamflow characteristics as limiting factors on benthic invertebrate assemblages in streams across the western United States. Freshwater Biology 53: 1983-1998.
Kundzewicz ZW, Mata LJ, Arnell NW, Doll P, Kabat P, Jimenez B, Miller KA, Oki T, Sen Z, Shiklomanov IA. 2007. Freshwater resources and their management. In Climate Change 2007: Impacts, Adaptation and Vulnerability. Contribution of Working Group II to the Fourth Assessment Report of the Intergovernmental Panel on Climate Change, Parry ML, Canziani OF, Palutikof JP, van der Linden PJ, Hanson CE (eds). Cambridge University Press: Cambridge, U.K.

Labbe TR, Fausch KD. 2000. Dynamics of intermittent stream habitat regulate persistence of a threatened fish at multiple scales. Ecological Applications 10: 1774-1791.

Lamouroux N, Cattaneo F. 2006. Fish assemblages and stream hydraulics: consistent relations across spatial scales and regions. River Research and Applications 22: 727-737.

Larimore RW, Childers WF, Heckrotte C. 1959. Destruction and reestablishment of stream fish and invertebrates affected by drought. Transactions of the American Fisheries Society 88: 261-285.

Leavesley GH, Stannard LG. 1995. The Precipitation-Runoff Modeling System-PRMS. In Computer Models of Watershed Hydrology, Singh VP (ed.). Water Resources Publications: Highlands Ranch, Colorado; 281-310

Leavesley GH, Lichty RW, Troutman BM, Saindon LG. 1983. Precipitationrunoff modeling system: user's manual. U.S. Geological Survey Water Resources Investigations Report 83-4238. 207.

Levins R. 1969. Some demographic and genetic consequences of environmental heterogeneity for biological control. Bulletin of the Entomological Society of America 15: 237-240.

Magoulick DD, Kobza RM. 2003. The role of refugia for fishes during drought: a review and synthesis. Freshwater Biology 48: 1186-1198.

McCargo JW, Peterson JT. 2010. An evaluation of the influence of seasonal base flow and geomorphic stream characteristics on Coastal Plain stream fish assemblages. Transactions of the American Fisheries Society 139: $29-48$.

Meador MR, Goldstein RM. 2003. Assessing water quality at large geographic scales: relations among land use, water physiochemistry, riparian condition, and fish community structure. Environmental Management 31: 504-517.

Milly PCD, Betancourt J, Falkenmark M, Hirsch RM, Kundzewicz ZW, Lettenmaier DP, Stouffer RJ. 2008. Stationarity is dead: whither water management? Science 319: 573-574.

Montgomery DR. 1999. Process domains and the river continuum. Journal of the American Water Resources Association 35: 397-410.

Morales Y, Weber LJ, Mynett AE, Newton TJ. 2006. Mussel dynamics model: a hydroinformatics tool for analyzing the effects of different stressors on the dynamics of freshwater mussel communities. Ecological Modelling 197: 448-460.

Naiman RJ, Latterell JJ, Pettit NE, Olden JD. 2008. Flow variability and the biophysical vitality of river systems. Comptes Rendus Geoscience 340: 629-643.

Nash JE, Sutcliffe JV. 1970, River flow forecasting through conceptual models part I-A discussion of principles. Journal of Hydrology 10: 282-290.

Nelson KC, Palmer MA, Pizzuto JE, Moglen GE, Angermeier PL, Hilderbrand RH, Dettinger M, Hayhoe K. 2009. Forecasting the combined effects of urbanization and climate change on stream ecosystems: from impacts to management options. Journal of Applied Ecology 46: 154-163.

Osborne LL, Wiley MJ. 1992. Influence of tributary spatial position on the structure of warmwater fish communities. Canadian Journal of Fisheries and Aquatic Sciences 49: 671-681.

Palmer MA, Liermann CAR, Nilsson C, Florke M, Alcamo J, Lake PS, Bond N. 2008. Climate change and the world's river basins: anticipating management options. Frontiers in Ecology and the Environment 6: 81-89.

Paul MJ, Meyer JL. 2001. Streams in the urban landscape. Annual Review of Ecology and Systematics 32: 333-365. 
Peterson JT, Kwak TJ. 1999. Modeling the effects of land use and climate change on riverine smallmouth bass. Ecological Applications 9: $1391-1404$.

Peterson JT, Jackson CR, Shea CP, Li G. 2009. Development and evaluation of a stream channel classification for estimating fish responses to changing streamflow. Transactions of the American Fisheries Society 138: 1123-1137.

Peterson JT, Wisniewski JM, Shea CP, Jackson CR. 2011. Estimation of mussel population response to hydrologic alteration in a southeastern U.S. stream. Environmental Management 48: 109-122.

Petts GE. 2009. Instream flow science for sustainable river management. Journal of the American Water Resources Association 45: 1071-1086.

Poff NL, Zimmerman JKH. 2010. Ecological responses to altered flow regimes: a literature review to inform science and management of environmental flows. Freshwater Biology 55: 194-205.

Poff NL, Richter BD, Arthington AH, Bunn SE, Naiman RJ, Kendy E, Acreman M, Apse C, Bledsoe BP, Freeman MC, Henriksen J, Jacobson RB, Kennen JG, Merritt DM, O' Keeffe JH, Olden JD, Rogers K, Tharme RE, Warner A. 2010. The ecological limits of hydrologic alteration (ELOHA): a new framework for developing regional environmental flow standards. Freshwater Biology 55: 147-170.

Postel SL. 2000. Entering an era of water scarcity: the challenges ahead. Ecological Applications 10: 941-948.

Postel S, Richter B. 2003. Rivers for Life: Managing Water for People and Nature. Island Press: Washington DC.

Power ME, Dietrich WE, Finlay JC. 1996. Dams and downstream aquatic biodiversity: potential food web consequences of hydrologic and geomorphic change. Environmental Management 20: 887-895.

Pringle CM. 2001. Hydrologic connectivity and the management of biological reserves: a global perspective. Ecological Applications 11: 981-998.

Pringle CM, Freeman MC, Freeman BJ. 2000. Regional effects of hydrologic alterations on riverine macrobiota in the New World: tropicaltemperate comparisons. BioScience 50: 807-823.

Rabeni CF, Jacobson RB. 1993. The importance of fluvial hydraulics to fish habitat restoration in low gradient alluvial streams. Freshwater Biology 29: 211-220.

Rabeni CF, Sowa SP. 2002. A landscape approach to managing the biota of rivers and streams. In Integrating Landscape Ecology into Natural Resource Management, Liu J, Taylor WW (eds). Cambridge University Press: Cambridge, UK; 114-142.

Railsback SF, Harvey BC, Jackson SK, Lamberson RH. 2009. InSTREAM: the individual-based stream trout research and environmental assessment model. Gen. Tech. Rep. PSW-GTR-218. Albany, CA: U.S. Department of Agriculture, Forest Service, Pacific Southwest Research Station, 254.

Richter BD, Warner AT, Meyer JL, Lutz K. 2006. A collaborative and adaptive process for developing environmental flow recommendations. River Research and Applications 22: 297-318.

Riley JW. 2009. Assessing Morphological Adjustments of Stream Channels in the Piedmont region of Georgia, USA. MS thesis, University of Georgia, Athens, GA. 192.

Riley JW, Jacobson RB. 2009. Long-term stage, stage residual, and width data for streams in the Piedmont physiographic region, Georgia. US Geological Survey OFR 2009-1205, Reston, VA.
Roy AH, Freeman MC, Freeman BJ, Wenger SJ, Ensign WE, Meyer JL. 2005. Investigating hydrologic alteration as a mechanism of fish assemblage shifts in urbanizing streams. Journal of the North American Benthological Society 24: 656-678.

Ruiz J, Peterson JT. 2007. An evaluation of the relative influence of spatial, statistical and biological factors on the accuracy of stream fish species presence models. Transactions of the American Fisheries Society 136: $1640-1653$.

Sabo JL, Sinha T, Bowling LC, Schoups GHW, Wallender WW, Campana ME, Cherkauer KA, Fuller PL, Graf WL, Hopmans JW, Kominoski JS, Taylor C, Trimble SW, Webb RH, Wohl EE. 2010. Reclaiming freshwater sustainability in the Cadillac Desert. Proceedings of the National Academy of Sciences 107: 21263-21270.

Schumm SA. 2005. RiverVariability and Complexity. Cambridge University Press: Cambridge UK.

Stelter C, Reich M, Grimm V, Wissel C. 1997. Modelling persistence in dynamic landscapes: lessons from a metapopulation of the grasshopper Bryodema tuberculata. Journal of Animal Ecology 66: 508-518.

Tetzlaff D, Soulsby C, Bacon PJ, Youngson AF, Gibbins C, Malcolm IA. 2007. Connectivity between landscapes and riverscapes - a unifying theme in integrating hydrology and ecology in catchment science? Hydrological Processes 21: 1385-1389.

Thorp JH, Thoms MC, Delong MD. 2006. The riverine ecosystem synthesis: biocomplexity in river networks across space and time. River Research and Applications 22: 123-147.

Trimble SW. 1974. Man-induced Soil Erosion on the Southern Piedmont, 1700-1970. Soil Conservation Society of America: Ankeny Iowa.

Van Winkle W, Jager HI, Railsback SF, Holcomb BD, Studley TK, Baldridge JE. 1998. Individual-based model of sympatric populations of brown and rainbow trout for instream flow assessment: model description and calibration. Ecological Modelling 110: 175-207.

Vaughan IP, Diamond M, Gurnell AM, Hall KA, Jenkins A, Milner NJ, Naylor LA, Sear DA, Woodward G, Ormerod SJ. 2009. Integrating ecology with hydromorphology: a priority for river science and management. Aquatic Conservation: Marine and Freshwater Ecosystems 19: 113-125.

Viger RJ, Hay LE, Jones JW, Buell GR. 2010. Effects of including surface depressions in the application of the Precipitation-Runoff Modeling System in the Upper Flint River Basin, Georgia. U.S. Geological Survey Scientific Investigations Report 2010-5062.

Viger RJ, Hay LE, Markstrom SL, Jones JW, Buell GR. 2011. Hydrologic effects of urbanization and climate change on the Flint River basin, Georgia. Earth Interactions 15: 1-25.

Walter RC, Merritts DJ. 2008. Natural streams and the legacy of waterpowered mills. Science 319: 299-304.

Williams BK, Szaro RC, Shapiro CD. 2007. Adaptive Management: the U. S. Department of Interior Technical Guide. Adaptive Management Working Group, U. S. Department of the Interior, Washington DC, 72.

Williams JD, Bogan AC, Garner JT. 2008. Freshwater Mussels of Alabama and the Mobile Basin in Georgia, Mississippi, and Tennessee. University of Alabama Press: Tuscaloosa, Alabama.

Wintle BA, Bekessy SA, Venier LA, Pearce JL, Chisholm RA. 2005. Utility of dynamic-landscape metapopulation models for sustainable forest management. Conservation Biology 19: 1930-1943. 